\title{
PCR and DGGE Detection Limits for Wine Spoilage Microbes
}

\author{
L. Bester ${ }^{1}$, M. Cameron ${ }^{1}$, M. du Toit ${ }^{2}$ and R.C. Witthuhn ${ }^{1 *}$
}

(1) Department of Food Science, Stellenbosch University, Private Bag X1, Matieland 7602, South Africa

(2) Institute for Wine Biotechnology, Department of Viticulture and Oenology, Stellenbosch University, Private Bag X1, Matieland 7602, South Africa

Submitted for publication: October 2009

Accepted for publication: January 2010

Key words: PCR-DGGE, wine, spoilage microbes, detection limits

\begin{abstract}
In this study the culture-independent technique, polymerase chain reaction (PCR)-denaturing gradient gel electrophoresis (DGGE), was investigated for the early detection and identification of possible spoilage microbes in wine. PCR and DGGE conditions were successfully optimised with the universal primers HDA1 ${ }^{\mathrm{GC}}$ and HDA2, the bacteria-specific primers WBAC1 ${ }^{\mathrm{GC}}-\mathrm{WBAC} 2$, and the yeast-specific primers $\mathrm{NL1}^{\mathrm{GC}}$ and LS2. PCR and DGGE detection limits were determined for Lactobacillus plantarum, Pediococcus pentosaceus, Acetobacter pasteurianus and Brettanomyces bruxellensis when inoculated into sterile saline solution (SSS) and white wine at $10^{6} \mathrm{cfu} / \mathrm{mL}$ respectively. PCR detection limits were more sensitive $\left(10^{1}\right.$ to $\left.10^{2} \mathrm{cfu} / \mathrm{mL}\right)$ than DGGE detection limits $\left(1^{1}\right.$ to $10^{4} \mathrm{cfu} /$ $\mathrm{mL}$ ), with the exception of $B$. bruxellensis, which had higher PCR and DGGE detection limits than the other reference microbes. PCR-DGGE analysis was also used successfully to detect and identify Lb. plantarum, A. pasteurianus and $B$. bruxellensis at a concentration of $10^{8} \mathrm{cfu} / \mathrm{mL}$ as part of mixed populations in SSS and white wine. PCR detection limits of $10^{1} \mathrm{cfu} / \mathrm{mL}$ were determined for all three reference microbes in mixed populations. The DGGE detection limits were higher for mixed populations when compared to single strains.
\end{abstract}

\section{INTRODUCTION}

Wine is the product of complex microbiological processes, with interactions between diverse species of yeasts, bacteria and mycelial fungi (Fleet, 1993; Querol \& Ramón, 1996). Saccharomyces cerevisiae is important in winemaking, since they are responsible for alcoholic fermentation. However, yeasts can also cause spoilage during fermentation, ageing and after bottling (Fleet, 1993). The main fermenting yeast that dominates during alcoholic fermentation is Saccharomyces cerevisiae, and today it is mostly added as a selected pure starter culture.

It is not only yeasts that are important in winemaking, but bacteria also play an important role in wine quality (Andorrà et al., 2008) and are represented by two groups, namely lactic acid bacteria (LAB) and acetic acid bacteria (AAB). Oenococcus oeni is mainly responsible for malolactic fermentation (MLF), but other genera of LAB, such as Lactobacillus, Leuconostoc and Pediococcus, also play a key role in winemaking and may cause wine spoilage under specific conditions (Rankine, 1995). AAB such as Acetobacter aceti and Acetobacter pasteurianus are present in wine and may cause volatile acidity through the oxidation of ethanol to acetaldehyde and acetic acid (Fleet, 1993).

Most microbial species in wine have been identified using conventional microbiological methods (Lopez et al., 2003). However, these methods have limitations in the identification and classification of microbes (Muyzer, 1999), and are often time consuming and labour intensive (Hernán-Gómez et al., 2000; Kopke et al., 2000). It is often difficult to assess the true microbial diversity in an ecosystem (Giraffa \& Neviani, 2001) and to cultivate all the viable microbes because of the complex conditions under which these microbes grow in their natural environment (Muyzer, 1999).
Culture-independent molecular techniques make it possible to study the total microbial DNA isolated from mixed microbial populations in order to detect, identify and characterise individual microbes in food ecosystems (Hugenholtz \& Pace, 1996). Genetic fingerprinting of complex microbial populations (Muyzer, 1999) is currently used extensively to study the microbial ecology of wine fermentations (Cocolin et al., 2000; Mills et al., 2002; Renouf et al., 2007). Polymerase chain reaction (PCR)-denaturing gradient gel electrophoresis (DGGE) analysis is also used, since it allows the detection and identification of individual species, as well as the overall profiling of microbial populations (Stahl \& Chapman, 1994).

The aim of this study was to evaluate three primer pairs, including universal, bacteria-specific and yeast-specific, for the identification and detection of microbes present in wine. The detection limit for each wine spoilage microbe (Lactobacillus plantarum, Pediococcus pentosaceus, Acetobacter pasteurianus and Brettanomyces bruxellensis) in sterile saline solution (SSS) and sterile white wine was determined with the three primer pairs using PCR-based DGGE analysis. Lactobacillus plantarum, A. pasteurianus and $B$. bruxellensis were also inoculated as mixed microbial populations in order to determine the detection limits of the reference microbes when present in mixed populations.

\section{MATERIALS AND METHODS}

\section{Microbial strains, media and growth conditions}

The reference microbial species and strains selected for the study were the LAB P. pentosaceus LMG 1361 and L. plantarum LMG 13556, the AAB A. pasteurianus DSM $3509^{\mathrm{T}}$, and the yeast $B$. bruxellensis ISA 1649. The microbes and their specific culturing requirements are summarised in Table 1 . The standard growth

*Corresponding author: e-mail: rcwit@sun.ac.za

Acknowledgements: The authors would like to express their gratitude to Winetech and THRIP for financial support. 
curves of each reference microbe were used to determine the inoculum size.

\section{Inoculation with single strains}

Sauvignon blanc white wine, produced at the Department of Viticulture and Oenology, Stellenbosch University during the 2008 season and sterilised with Velcorin (Sigma-Aldrich), and SSS were inoculated with $10^{6} \mathrm{cfu} / \mathrm{mL}$ of a specific wine microbial strain (L. plantarum, P. pentosaceus, A. pasteurianus or B. bruxellensis) to determine PCR-based DGGE detection limits for the universal, bacteria-specific and yeast-specific primers. The wine was sterilised with Velcorin (Sigma-Aldrich) $48 \mathrm{~h}$ before inoculation of the reference microbes. Velcorin was prepared and diluted in a 1:4 ratio with $100 \%$ ethanol (Merck), and $200 \mu \mathrm{L} / \mathrm{L}$ of the dilution was added to the wine.
A $100 \mathrm{~mL}$ sample of both sterile white wine and SSS was inoculated with a single microbial strain at a concentration of $10^{6} \mathrm{cfu} / \mathrm{mL}$. A dilution series of the inoculated SSS and sterile white wine was made in SSS, and each dilution was pour plated (in duplicate) on the appropriate cell count agar (Table 2), after which the plates were incubated and the colonies were counted. Sterile white wine and SSS served as controls and no growth was detected after incubation. PCR and DGGE detection limits were also determined for each dilution. All experiments were done in triplicate.

\section{Inoculation with mixed strains}

Lactobacillus plantarum was selected as a representative wine $\mathrm{LAB}, A$. pasteurianus as a representative wine $\mathrm{AAB}$, and $B$. bruxellensis as the representative wine yeast. SSS and sterile

\section{TABLE 1}

Culturing media, incubation times and temperatures used for the reference microbes in SSS and sterile white wine.

\begin{tabular}{|c|c|c|c|c|}
\hline Microbe & Culturing media & $\mathbf{p H}^{\mathbf{a}}$ & $\begin{array}{c}\text { Incubation } \\
\text { time (h) }\end{array}$ & $\begin{array}{c}\text { Incubation } \\
\text { temperature }\left({ }^{\circ} \mathrm{C}\right)\end{array}$ \\
\hline Pediococcus pentosaceus & $\begin{array}{l}\text { MRS }^{\mathrm{b}} \text { supplemented with } \\
40 \mathrm{~g} / \mathrm{L} \mathrm{D}(-) \text { fructose (Merck), } \\
20 \mathrm{~g} / \mathrm{L} \mathrm{D}(+) \text { glucose (Merck), } \\
4 \mathrm{~g} / \mathrm{L} \mathrm{L}(-) \text { malic acid (Merck), } \\
1 \mathrm{~g} / \mathrm{L} \text { Tween } 80 \text { (Merck) and } \\
4 \%(\mathrm{v} / \mathrm{v}) \text { ethanol }\end{array}$ & 4.6 & 48 & 30 \\
\hline Lactobacillus plantarum & $\begin{array}{l}\text { MRS supplemented with } \\
40 \mathrm{~g} / \mathrm{L} \mathrm{D}(-) \text { fructose (Merck), } \\
20 \mathrm{~g} / \mathrm{L} \mathrm{D}(+) \text { glucose (Merck), } \\
4 \mathrm{~g} / \mathrm{L} \mathrm{L}(-) \text { malic acid (Merck), } \\
1 \mathrm{~g} / \mathrm{L} \mathrm{Tween} 80 \text { (Merck) and } \\
4 \%(\mathrm{v} / \mathrm{v}) \text { ethanol }\end{array}$ & 4.6 & 48 & 30 \\
\hline Acetobacter pasteurianus & MRS supplemented with $2 \%(\mathrm{v} / \mathrm{v})$ ethanol & 5.5 & 72 & 30 \\
\hline Brettanomyces bruxellensis & $\begin{array}{l}\text { YPD }{ }^{c} \text { supplemented with } \\
6 \%(\mathrm{v} / \mathrm{v}) \text { ethanol }\end{array}$ & 6.5 & 96 & 25 \\
\hline
\end{tabular}

${ }^{a} \mathrm{pH}$ adjusted with $1 \mathrm{M} \mathrm{HCl}$ according to The South African Wine Laboratories Association (2002).

${ }^{\mathrm{b}} \mathrm{MRS}=$ de Man, Rogosa and Sharpe broth (Biolab).

${ }^{\mathrm{C}} \mathrm{YPD}=$ yeast peptone dextrose broth (Biolab).

\section{TABLE 2}

Cell count agar, incubation times and temperatures used for the reference microbes inoculated as mixed cultures in SSS and sterile white wine.

\begin{tabular}{|c|c|c|c|c|c|}
\hline Microbe & Agar & $\mathbf{p H}^{\mathbf{a}}$ & $\begin{array}{l}\text { Incubation } \\
\text { time (d) }\end{array}$ & $\begin{array}{c}\text { Incubation } \\
\text { temperature }\left({ }^{\circ} \mathrm{C}\right)\end{array}$ & $\begin{array}{l}\text { Antibiotics } \\
\text { (mg/L) }\end{array}$ \\
\hline Lactobacillus plantarum & $\mathrm{MRS}^{\mathrm{b}}$ & 6.5 & $5-7$ & 30 & $\begin{array}{l}\text { Actistab; } 100 \\
\text { Kanamycin sulphate; } 25\end{array}$ \\
\hline Acetobacter pasteurianus & MRS supplemented with $2 \%(v / v)$ ethanol & 5.5 & $5-7$ & 30 & $\begin{array}{l}\text { Actistab; } 100 \\
\text { Streptomycin sulphate; } 25\end{array}$ \\
\hline Brettanomyces bruxellensis & $\mathrm{DBDM}^{\mathrm{c}}$ agar & 5.4 & $11-14$ & 25 & $\begin{array}{l}\text { Streptomycin sulphate; } 25 \\
\text { Kanamycin sulphate; } 25\end{array}$ \\
\hline
\end{tabular}

${ }^{a} \mathrm{pH}$ adjusted with $1 \mathrm{M} \mathrm{HCl}$ according to The South African Wine Laboratories Association (2002).

${ }^{\mathrm{b}} \mathrm{MRS}=$ de Man, Rogosa and Sharpe broth (Biolab).

${ }^{\mathrm{c} D B D M}=$ Dekkera/Brettanomyces differential medium (6.7 g/L yeast nitrogen base YNB (Difco), $100 \mathrm{mg} / \mathrm{L}$ p-coumaric acid (Sigma-Aldrich), $22 \mathrm{mg} / \mathrm{L}$ bromocresol green (Merck), 6\% (v/v) ethanol and $20 \mathrm{~g} / \mathrm{L}$ bacteriological agar (Biolab)) (Rodrigues et al., 2001). 
white wine were inoculated with mixed microbial populations containing $10^{8} \mathrm{cfu} / \mathrm{mL}$ of each of the representative strains in order to determine PCR-DGGE detection limits for the universal and bacteria-specific primers with the mixtures of microbes. The standard growth curves of each reference microbe were used to determine the inoculum size. The following combinations of $L$. plantarum, A. pasteurianus and B. bruxellensis were inoculated into SSS and sterile white wine: L. plantarum, A. pasteurianus and B. bruxellensis; L. plantarum and B. bruxellensis; L. plantarum and A. pasteurianus; or B. bruxellensis and A. pasteurianus.

A dilution series of the inoculated SSS and sterile white wine was made in SSS, and each dilution was pour plated (in duplicate) on the appropriate cell count agar, after which the plates were incubated and the colonies were enumerated (Table 2). The cell count agar was supplemented with specific antibiotics in order to eliminate the growth of unwanted yeasts, AAB and LAB. Sterile white wine and SSS served as controls and no growth was detected after incubation. PCR and DGGE detection limits were also determined for each dilution. All experiments were done in triplicate.

\section{DNA isolation}

DNA was extracted from the inoculated microbes in the SSS, as well as from the white wine. DNA isolation was carried out according to the modified method of Wang and Levin (2006). Two $\mathrm{mL}$ of the inoculated medium was centrifuged for $10 \mathrm{~min}$ at $6000 \mathrm{x}$, after which the supernatant was discarded. The pellet was re-suspended in $250 \mu \mathrm{L}$ of SSS, and $250 \mu \mathrm{L}$ of the suspension was mixed with $250 \mu \mathrm{L}$ double-strength TZ $(2 \times \mathrm{TZ})$, consisting of $4 \%(\mathrm{v} / \mathrm{v})$ Triton $\mathrm{X}-100$ (Merck) and $5 \mathrm{mg} / \mathrm{mL}$ sodium azide (Merck) in $0.1 \mathrm{M}$ Tris$\mathrm{HCl}$ (Fluka); $\mathrm{pH}$ 8.0. The sample tubes were boiled for $10 \mathrm{~min}$ in a water bath to lyse the cells, after which the microcentrifuge tubes were placed on ice for $5 \mathrm{~min}$. The microcentrifuge tubes were then centrifuged for $5 \mathrm{~min}$ at $10000 \mathrm{x} g$ and $200 \mu \mathrm{L}$ of the supernatant was extracted and purified using a Micropure-EZ column (Millipore). All experiments were done in triplicate.

\section{PCR}

The V3 variable region of the $16 \mathrm{~S}$ ribosomal RNA (rRNA) gene for the bacterial reference strains, and the D1/D2 region of the 26S rRNA gene for the yeast reference strain were amplified using the universal primers $\mathrm{HDA} 1^{\mathrm{GC}}\left(5^{\prime}\right.$-CGC CCG CCG CGC CCC GCG CCC GTC CCG CCG CCC CCG CCC G ACT CCT ACG GGA GGC AGC AGT-3') and HDA2 (5' - GTA TTA CCG CGG CTG CTG GCA C-3') (250 bp fragment) (Lopez et al., 2003). To facilitate DGGE separation, a GC-rich sequence (GC clamp sequence is underlined) was attached to the forward primer. The PCR reactions were performed in a total volume of $40 \mu \mathrm{L}$ containing $1 \times$ PCR buffer, $2.5 \mathrm{mM} \mathrm{MgCl}_{2}, 0.8 \mathrm{mM}$ dNTPs, $0.5 \mu \mathrm{M}$ of each primer, 1.5 U Taq DNA polymerase (Super-Therm, Southern Cross Biotechnology, Cape Town, South Africa) and $2 \mu \mathrm{L}$ of DNA template. Thermal cycling was carried out with a thermal cycler (Eppendorf Mastercycler Personal, Merck, Hamburg, Germany) with an initial denaturation at $94^{\circ} \mathrm{C}$ for $4 \mathrm{~min}$, followed by 30 cycles of denaturation at $94^{\circ} \mathrm{C}$ for $30 \mathrm{~s}$, annealing at $56^{\circ} \mathrm{C}$ for $30 \mathrm{~s}$ and elongation at $68^{\circ} \mathrm{C}$ for $60 \mathrm{~s}$. A final elongation at $68^{\circ} \mathrm{C}$ for $7 \mathrm{~min}$ was also performed.

The V7 to V8 variable region of the $16 \mathrm{~S}$ rRNA gene for the bacterial reference strains was amplified using the bacteriaspecific primers WBAC $1^{\mathrm{GC}}$ (5'-CGC $\underline{\text { CCG CCG CGC CCC GCG }}$
CCC GGC CCG CCG CCC CCC CCC GGT CGT CAG CTC GTG TCG TGA GA-3') and WBAC2 (5'-CCC GGG AAC GTA TTC ACC GCG-3') (GC clamp sequence is underlined) (320 bp fragment), which are based on the primers described by Lopez et al. (2003). According to Lopez et al. (2003), no specific primers have been reported for $\mathrm{AAB}$ and the $\mathrm{WBAC} 1^{\mathrm{GC}}-\mathrm{WBAC} 2$ primers could successfully be used for the amplification of both $\mathrm{LAB}$ and $\mathrm{AAB}$ associated with wine. The PCR reactions were performed in a total volume of $50 \mu \mathrm{L}$, containing 1 x PCR buffer, $1.5 \mathrm{mM} \mathrm{MgCl}_{2}, 0.8$ mM dNTPs, $0.2 \mu \mathrm{M}$ of each primer, $2.5 \mathrm{U}$ Taq DNA polymerase (Super-Therm) and $3 \mu \mathrm{L}$ of DNA template. Thermal cycling was carried out with an initial denaturation at $95^{\circ} \mathrm{C}$ for $5 \mathrm{~min}$, followed by 30 cycles of denaturation at $95^{\circ} \mathrm{C}$ for $60 \mathrm{~s}$, annealing at $57^{\circ} \mathrm{C}$ for $30 \mathrm{~s}$ and elongation at $72^{\circ} \mathrm{C}$ for $60 \mathrm{~s}$. A final elongation at $72^{\circ} \mathrm{C}$ for 5 min was also performed during the reaction.

The D1/D2 region of the 26S rRNA gene of the yeast reference strain was amplified using the yeast-specific primers $\mathrm{NL}^{\mathrm{GC}}\left(5^{\prime}\right.$ CGC CCG CCG CGC GCG GCG GGC GGG GCG GGG GCC ATA TCA ATA AGC GGA GGA AAA G-3') and LS2 (5'-ATT CCC AAA CAA CTC GAC TC-3') (GC clamp sequence is underlined) (250 bp fragment) (O'Donnell, 1993). The PCR reactions were performed in a total volume of $25 \mu \mathrm{L}$ containing $1 \times$ PCR buffer, $3 \mathrm{mM} \mathrm{MgCl}, 0.4 \mathrm{mM}$ dNTPs, $0.6 \mu \mathrm{M}$ of each primer, 1.25 U Taq DNA polymerase (Super-Therm), $1 \mu \mathrm{L}$ 99\% (v/v) dimethyl sulphoxide (DMSO) (Merck) and $1 \mu \mathrm{L}$ of DNA template. The PCR reaction consisted of an initial 5 min denaturation at $95^{\circ} \mathrm{C}$, followed by 30 cycles of denaturation at $95^{\circ} \mathrm{C}$ for $60 \mathrm{~s}$, annealing at $52^{\circ} \mathrm{C}$ for $45 \mathrm{~s}$ and elongation at $72^{\circ} \mathrm{C}$ for $60 \mathrm{~s}$. The reaction was completed with a final elongation at $72^{\circ} \mathrm{C}$ for $7 \mathrm{~min}$.

The PCR amplicons, together with a positive and negative control, were separated on a $1.5 \%(\mathrm{~m} / \mathrm{v})$ agarose gel (stained with $0.02 \mu \mathrm{L} / \mathrm{mL}$ ethidium bromide) in $0.5 \mathrm{x}$ TBE electrophoresis buffer. The PCR fragments were visualised under an ultraviolet transilluminator (Vilber Lourmat, Marne-La-Vallée, France).

\section{DGGE analysis}

The PCR fragments obtained from the amplification using the HDA $1^{\mathrm{GC}}-\mathrm{HDA} 2$, WBAC1 ${ }^{\mathrm{GC}}-\mathrm{WBAC} 2$ and $\mathrm{NL} 1^{\mathrm{GC}}-\mathrm{LS} 2$ primers were resolved using DGGE analysis, performed with the BioRad DCode Universal Mutation Detection System (BioRad Laboratories, Cape Town, South Africa). PCR products were applied directly onto $8 \%(\mathrm{~m} / \mathrm{v})$ polyacrylamide gels with a denaturing gradient of between $45 \%$ and $70 \%$ of $7 \mathrm{M}$ urea (Merck) and $40 \%(\mathrm{v} / \mathrm{v})$ formamide (Merck) in a $1 \mathrm{x}$ TAE buffer. The electrophoresis was performed at a constant voltage of $130 \mathrm{mV}$ for $5 \mathrm{~h}$ and a constant temperature of $60^{\circ} \mathrm{C}$. The gels were stained in $1 \mathrm{x}$ TAE buffer containing ethidium bromide $(94 \mu \mathrm{l} / \mathrm{L})$, and the fragments were visualised under an ultraviolet transilluminator (Vilber Lourmat).

\section{RESULTS AND DISCUSSION}

\section{Optimisation of PCR-DGGE}

The universal primers, HDA1 ${ }^{\mathrm{GC}}-\mathrm{HDA} 2$, the bacteria-specific primers, WBAC $1{ }^{\mathrm{GC}}-\mathrm{WBAC} 2$, as well as the yeast-specific primers NL1 ${ }^{\mathrm{GC}}-\mathrm{LS} 2$, were selected for the amplification of DNA isolated from the reference microbes $P$. pentosaceus, L. plantarum, A. pasteurianus and $B$. bruxellensis. The primers successfully amplified the specific yeast and bacterial species evaluated in this study. 
Amplicons obtained after PCR amplification were successfully resolved using DGGE analysis. Approximately $250 \mathrm{bp}$ amplicons, amplified with the HDA1 ${ }^{\mathrm{GC}}$-HDA2 primers, were successfully resolved using DGGE analysis. Pediococcus pentosaceus and $B$. bruxellensis showed the same migration distances in the DGGE gel. This means that it would not be possible to distinguish these two microbial species from each other on a DGGE gel when amplified using these universal primers.

The 320 bp amplicons, amplified with the WBAC1 $1^{\mathrm{GC}}-\mathrm{WBAC} 2$ primers, were found to have different migration distances in the DGGE gel, and it would thus be possible to distinguish between these bacterial strains when separated on a DGGE polyacrylamide gel. The reference bacteria would also have different positions in a reference ladder, which could be used for species identification.

The optimised DGGE conditions could be used for reference ladders, as an alternative to the sequencing of DGGE bands, to presumptively identify the microbial species (Ercolini, 2004) inoculated into SSS and sterile white wine. The identification of the microbial species is achieved by comparing the PCR fragment migration distances in the DGGE polyacrylamide gels with those of the reference species present (Ercolini, 2004).

\section{Detection limits for single microbes}

The performance of PCR-DGGE analysis for the detection and identification of wine spoilage yeasts and bacteria was evaluated and the results were confirmed with pour plating for enumeration. After PCR and DGGE optimisation, the limit of microbial detection by PCR-DGGE analysis was determined for
P. pentosaceus, L. plantarum, A. pasteurianus and B. bruxellensis when each microbial strain was separately inoculated into SSS and sterile white wine at $10^{6} \mathrm{cfu} / \mathrm{mL}$.

\section{Acetobacter pasteurianus}

The PCR and DGGE detection limits obtained for A. pasteurianus are summarised in Table 3. PCR amplicons were successfully obtained for the dilution samples when A. pasteurianus was inoculated into SSS and white wine and amplified with the HDA $1{ }^{\mathrm{GC}}-\mathrm{HDA} 2$ and WBAC1 ${ }^{\mathrm{GC}}-\mathrm{WBAC} 2$ primer pairs. The PCR detection limits were determined as $10^{1} \mathrm{cfu} / \mathrm{mL}$ in both SSS and white wine.

The PCR fragments were successfully resolved using DGGE analysis, and DGGE detection limits of $10^{2} \mathrm{cfu} / \mathrm{mL}$ were determined for A. pasteurianus when inoculated into SSS for both primer pairs. When the inoculation was done in white wine and the fragments amplified with the WBAC1 ${ }^{\mathrm{GC}}-\mathrm{WBAC} 2$ primers, a slightly higher DGGE detection limit of $10^{3} \mathrm{cfu} / \mathrm{mL}$ was determined than when the inoculation was done in SSS $\left(10^{2}\right.$ $\mathrm{cfu} / \mathrm{mL}$ ). As was the case for SSS, the DGGE detection limit for A. pasteurianus in white wine, and with the HDA1 $1^{\mathrm{GC}}-\mathrm{HDA} 2$ primers, was $10^{2} \mathrm{cfu} / \mathrm{mL}$.

\section{Lactobacillus plantarum}

When L. plantarum was inoculated into SSS and white wine, PCR detection limits of $10^{1} \mathrm{cfu} / \mathrm{mL}$ were determined when amplified with the HDA1 ${ }^{\mathrm{GC}}-\mathrm{HDA} 2$ primers (Table 3 ). When amplified with the bacteria-specific primers (WBAC1 $1^{\mathrm{GC}}-\mathrm{WBAC} 2$ ), a PCR

\section{TABLE 3}

PCR and DGGE detection limits for reference microbial strains inoculated singly $\left(10^{6} \mathrm{cfu} / \mathrm{mL}\right)$.

\begin{tabular}{|c|c|c|c|c|}
\hline Microbe & Inoculation medium & Primers & $\begin{array}{c}\text { PCR detection limit } \\
(\mathrm{cfu} / \mathrm{mL})\end{array}$ & $\begin{array}{l}\text { DGGE detection limit } \\
(\mathrm{cfu} / \mathrm{mL})\end{array}$ \\
\hline \multirow[t]{4}{*}{ A. pasteurianus } & SSS & $\mathrm{HDA} 1^{\mathrm{GC}} / \mathrm{HDA} 2$ & $10^{1}$ & $10^{2}$ \\
\hline & & $\mathrm{WBAC} 1^{\mathrm{GC}} / \mathrm{WBAC} 2$ & $10^{1}$ & $10^{2}$ \\
\hline & White wine & $\mathrm{HDA} 1{ }^{\mathrm{GC}} / \mathrm{HDA} 2$ & $10^{1}$ & $10^{2}$ \\
\hline & & $\mathrm{WBAC} 1^{\mathrm{GC}} / \mathrm{WBAC} 2$ & $10^{1}$ & $10^{3}$ \\
\hline \multirow[t]{4}{*}{ L. plantarum } & SSS & $\mathrm{HDA} 1{ }^{\mathrm{GC}} / \mathrm{HDA} 2$ & $10^{1}$ & $10^{1}$ \\
\hline & & WBAC1 $1 \mathrm{GC} / \mathrm{WBAC} 2$ & $10^{1}$ & $10^{2}$ \\
\hline & White wine & $\mathrm{HDA} 1{ }^{\mathrm{GC}} / \mathrm{HDA} 2$ & $10^{1}$ & $10^{2}$ \\
\hline & & $\mathrm{WBAC} 1 \mathrm{GC} / \mathrm{WBAC} 2$ & $10^{2}$ & $10^{3}$ \\
\hline \multirow[t]{4}{*}{ P. pentosaceus } & SSS & $\mathrm{HDA} 1{ }^{\mathrm{GC}} / \mathrm{HDA} 2$ & $10^{1}$ & $10^{1}$ \\
\hline & & $\mathrm{WBAC} 1 \mathrm{GC} / \mathrm{WBAC} 2$ & $10^{1}$ & $10^{2}$ \\
\hline & White wine & $\mathrm{HDA} 1{ }^{\mathrm{GC}} / \mathrm{HDA} 2$ & $10^{2}$ & $10^{2}$ \\
\hline & & $\mathrm{WBAC} 1 \mathrm{GC} / \mathrm{WBAC} 2$ & $10^{2}$ & $10^{4}$ \\
\hline \multirow[t]{4}{*}{ B. bruxellensis } & SSS & $\mathrm{HDA} 1{ }^{\mathrm{GC}} / \mathrm{HDA} 2$ & $10^{1}$ & $10^{4}$ \\
\hline & & $\mathrm{NL} 1{ }^{\mathrm{GC}} / \mathrm{LS} 2$ & $10^{4}$ & $10^{5}$ \\
\hline & White wine & $\mathrm{HDA} 1{ }^{\mathrm{GC}} / \mathrm{HDA} 2$ & $10^{3}$ & $10^{3}$ \\
\hline & & $\mathrm{NL} 1{ }^{\mathrm{GC}} / \mathrm{LS} 2$ & $10^{4}$ & $10^{5}$ \\
\hline
\end{tabular}


detection limit of $10^{1} \mathrm{cfu} / \mathrm{mL}$ was determined in SSS, with a slightly higher PCR detection limit of $10^{2} \mathrm{cfu} / \mathrm{mL}$ when white wine was used as the inoculation medium.

The PCR fragments were successfully resolved with DGGE analysis, and a DGGE detection limit of $10^{1} \mathrm{cfu} / \mathrm{mL}$ was determined when L. plantarum was inoculated into SSS and amplified with the universal primers (HDA1 ${ }^{\mathrm{GC}}$-HDA2) (Fig. 1). A DGGE detection limit of $10^{2} \mathrm{cfu} / \mathrm{mL}$ was found when the amplifications was done with the WBAC1 ${ }^{\mathrm{GC}}-\mathrm{WBAC} 2$ primers (Table 3 ). The DGGE limits in white wine were $10^{2} \mathrm{cfu} / \mathrm{mL}$ and $10^{3} \mathrm{cfu} / \mathrm{mL}$ for the universal and bacteria-specific primers respectively (Table 3 ).

\section{Pediococcus pentosaceus}

With the inoculation of $P$. pentosaceus into SSS, PCR detection limits of $10^{1} \mathrm{cfu} / \mathrm{mL}$ were determined for both the universal and the bacteria-specific primer pairs (Table 3). A slightly higher PCR detection limit of $10^{2} \mathrm{cfu} / \mathrm{mL}$ was determined for the HDA $1^{\mathrm{GC}}$ HDA2, as well as for the WBAC1 $1{ }^{\mathrm{GC}}-\mathrm{WBAC} 2$ primer pairs, with inoculation of $P$. pentosaceus into white wine.

The PCR fragments were resolved using DGGE analysis, and when $P$. pentosaceus was inoculated into SSS a DGGE detection limit of $10^{1} \mathrm{cfu} / \mathrm{mL}$ was determined for the PCR fragments amplified with the HDA $1{ }^{\mathrm{GC}}-\mathrm{HDA} 2$ primers. A DGGE detection limit of $10^{2} \mathrm{cfu} / \mathrm{mL}$ was determined for $P$. pentosaceus inoculated into SSS when amplified with the WBAC1 $1^{\mathrm{GC}}-\mathrm{WBAC} 2$ primers. The DGGE detection limit for $P$. pentosaceus in white wine was determined as $10^{2} \mathrm{cfu} / \mathrm{mL}$ when amplified with the universal primer pair (Table 3). When the fragments that had been amplified with the WBAC1 $1{ }^{\mathrm{GC}}-\mathrm{WBAC} 2$ primers were resolved with DGGE, a detection limit of $10^{4} \mathrm{cfu} / \mathrm{mL}$ was determined. It was found that it was possible to detect lower cell concentrations of $P$. pentosaceus with the HDA $1^{\mathrm{GC}}-\mathrm{HDA} 2$ primer pair in both the SSS and the white wine than with the WBAC1 $1^{\mathrm{GC}}-\mathrm{WBAC} 2$ primer pair.

\section{Brettanomyces bruxellensis}

PCR detection limits of $10^{1} \mathrm{cfu} / \mathrm{mL}$ and $10^{3} \mathrm{cfu} / \mathrm{mL}$ were determined when $B$. bruxellensis was amplified with the universal primers in SSS and white wine respectively (Table 3). When amplified with the yeast-specific primers NL1 ${ }^{\mathrm{GC}}-\mathrm{LS} 2$, a PCR detection limit of $10^{4} \mathrm{cfu} / \mathrm{mL}^{-1}$ was determined when $B$. bruxellensis was inoculated into both SSS and white wine. The PCR detection limits were higher than expected for the yeast B. bruxellensis, and generally higher than the detection limits determined for the reference wine bacteria.

A DGGE detection limit of $10^{4} \mathrm{cfu} / \mathrm{mL}$ was determined for SSS with the universal primers (HDA1 ${ }^{\mathrm{GC}}$-HDA2), and a DGGE detection limit of $10^{5} \mathrm{cfu} / \mathrm{mL}$ was observed when amplified with the yeastspecific primers ( $\left.\mathrm{NL}^{\mathrm{GC}}-\mathrm{LS} 2\right)$ (Table 3$)$. When $B$. bruxellensis was inoculated into white wine, a DGGE detection limit of $10^{3} \mathrm{cfu} / \mathrm{mL}$ was obtained with the universal primers. The $\mathrm{NL}^{\mathrm{GC}}-\mathrm{LS} 2$ primers could only resolve concentrations of $B$. bruxellensis of greater than $10^{5} \mathrm{cfu} / \mathrm{mL}$ in white wine and SSS with DGGE (Table 3), and did not give reproducible and reliable results for the determination of PCR and DGGE detection limits in white wine. This could possibly mean that the yeast-specific primer pair is less sensitive than the universal primers, thus more DNA is required for PCR amplification with the NL1 ${ }^{\mathrm{GC}}-\mathrm{LS} 2$ primer pair. This would suggest that $\mathrm{NL}^{\mathrm{GC}}{ }_{-}$ LS2 would not be a suitable primer pair for the detection of $B$. bruxellensis using PCR-based DGGE analysis.

The results obtained from the determination of PCR and DGGE detection limits, when $10^{6} \mathrm{cfu} / \mathrm{mL}$ of the reference microbial strains were separately inoculated into SSS and white wine, illustrated that the universal, bacteria-specific and yeast-specific primers used in this study could be used successfully to detect and identify spoilage microbes that are associated with winemaking. When the inoculations were done in white wine, higher detection limits were obtained than when the inoculations were done in

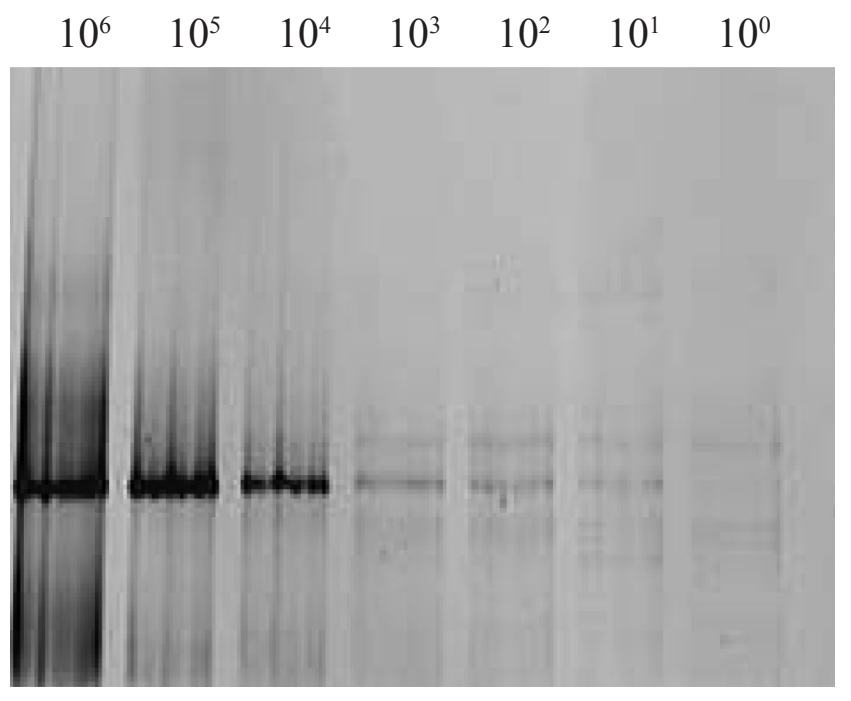

FIGURE 1

DGGE analysis of the different concentrations of L. plantarum $\left(10^{6}-10^{\circ} \mathrm{cfu} / \mathrm{mL}\right)$ inoculated into sterile saline solution and amplified with the primers HDA $1^{\mathrm{GC}}$ and HDA2. 
SSS. This may be due to the presence of inhibitors that are present in wine. Plant materials, such as polysaccharides, plant lipids and polyphenols are known to inhibit PCR reactions, which ultimately will also influence the outcome of the DGGE detection limit results (Lodhi et al., 1994). The plant material and inhibitory substances that were extracted during DNA isolation could also have had an influence on the PCR amplification of the DNA template, and could cause a decrease in the sensitivity of this detection method (Prakitchaiwattana et al., 2004). The sensitivity of the primers used in this study differed in terms of PCR and DGGE detection limits. PCR was found to be more sensitive than DGGE, as the PCR detection limits were found to be lower for most samples. The universal primers (HDA $1^{\mathrm{GC}}-\mathrm{HDA} 2$ ) and the bacteria-specific primers (WBAC1 $1{ }^{\mathrm{GC}}-\mathrm{WBAC} 2$ ) had similar sensitivity for the PCR amplification of the DNA templates from the inoculated samples.

\section{Detection limits for mixed microbes}

Several bacterial and yeast species are present in wine during alcoholic fermentation and MLF (Prakitchaiwattana et al., 2004). Detection limits of the reference microbes inoculated into SSS and white wine therefore were determined as part of a mixed population with the universal and bacteria-specific primers. Due to the high detection limits obtained with the NL1 ${ }^{\mathrm{GC}}-\mathrm{LS} 2$ primers, it was decided not to use this primer pair for the detection of $B$. bruxellensis in mixed microbial populations.

The performance of PCR-based DGGE analysis was thus evaluated in detecting individual wine microbial strains in cell suspensions containing a variety of microbial populations.

\section{Acetobacter pasteurianus and Lactobacillus plantarum}

When A. pasteurianus and L. plantarum were inoculated into SSS and white wine, a PCR detection limit of $10^{1} \mathrm{cfu} / \mathrm{mL}$ was obtained for both bacterial species when amplified with the HDA $1^{\mathrm{GC}}-\mathrm{HDA} 2$ and WBAC1 ${ }^{\mathrm{GC}}-\mathrm{WBAC} 2$ primers (Table 4$)$. The
PCR detection limits determined for these two bacteria compared well with the results for the detection limits of the single reference microbial strains inoculated into SSS and white wine. The PCR detection limits were observed as $10^{1} \mathrm{cfu} / \mathrm{mL}$ for both bacterial species, except for L. plantarum, which had a detection limit of $10^{2} \mathrm{cfu} / \mathrm{mL}$ when inoculated as a single strain in white wine and amplified with the WBAC1 ${ }^{\mathrm{GC}}-\mathrm{WBAC} 2$ primer pair (Table 3).

The DGGE detection limits in SSS were determined to be $10^{3}$ cfu $/ \mathrm{mL}$ for both $A$. pasteurianus and L. plantarum when amplified with the universal primers, and $10^{1} \mathrm{cfu} / \mathrm{mL}$ when amplified with the bacteria-specific primers. When A. pasteurianus and L. plantarum were inoculated into white wine, a DGGE detection limit of $10^{1} \mathrm{cfu} / \mathrm{mL}$ was determined for $A$. pasteurianus, and a higher detection limit of $10^{4} \mathrm{cfu} / \mathrm{mL}$ was found for L. plantarum when amplified with the HDA1 ${ }^{\mathrm{GC}}-\mathrm{HDA} 2$ primers (Table 4). When the PCR amplicons that were amplified with the WBAC1 ${ }^{\mathrm{GC}}-\mathrm{WBAC} 2$ primers were resolved using DGGE, a detection limit of $10^{1} \mathrm{cfu} /$ $\mathrm{mL}$ was determined for both $A$. pasteurianus and L. plantarum (Table 4). This primer pair was capable of amplifying a smaller amount of cells and was thus more sensitive than the HDA $1^{\mathrm{GC}}$ HDA2 primers in amplifying a mixed population of these wine bacteria. When compared to the DGGE detection limits of the reference microbes inoculated as single strains, it was observed that the HDA1 $1{ }^{\mathrm{GC}}-\mathrm{HDA} 2$ primer pair was more sensitive than the WBAC $1{ }^{\mathrm{GC}}-\mathrm{WBAC} 2$ primer pair in the detection of the single microbial strains, but as part of mixed populations it was observed that the WBAC1 ${ }^{\mathrm{GC}}-\mathrm{WBAC} 2$ primer pair was more sensitive.

\section{Acetobacter pasteurianus and Brettanomyces bruxellensis}

When the wine AAB, A. pasteurianus, and the wine yeast, $B$. bruxellensis, were inoculated into SSS and white wine, a PCR detection limit of $10^{1} \mathrm{cfu} / \mathrm{mL}$ was determined for both these microbes when amplified with both the universal and bacteriaspecific primers (Table 4). As was expected, the bacteria-specific

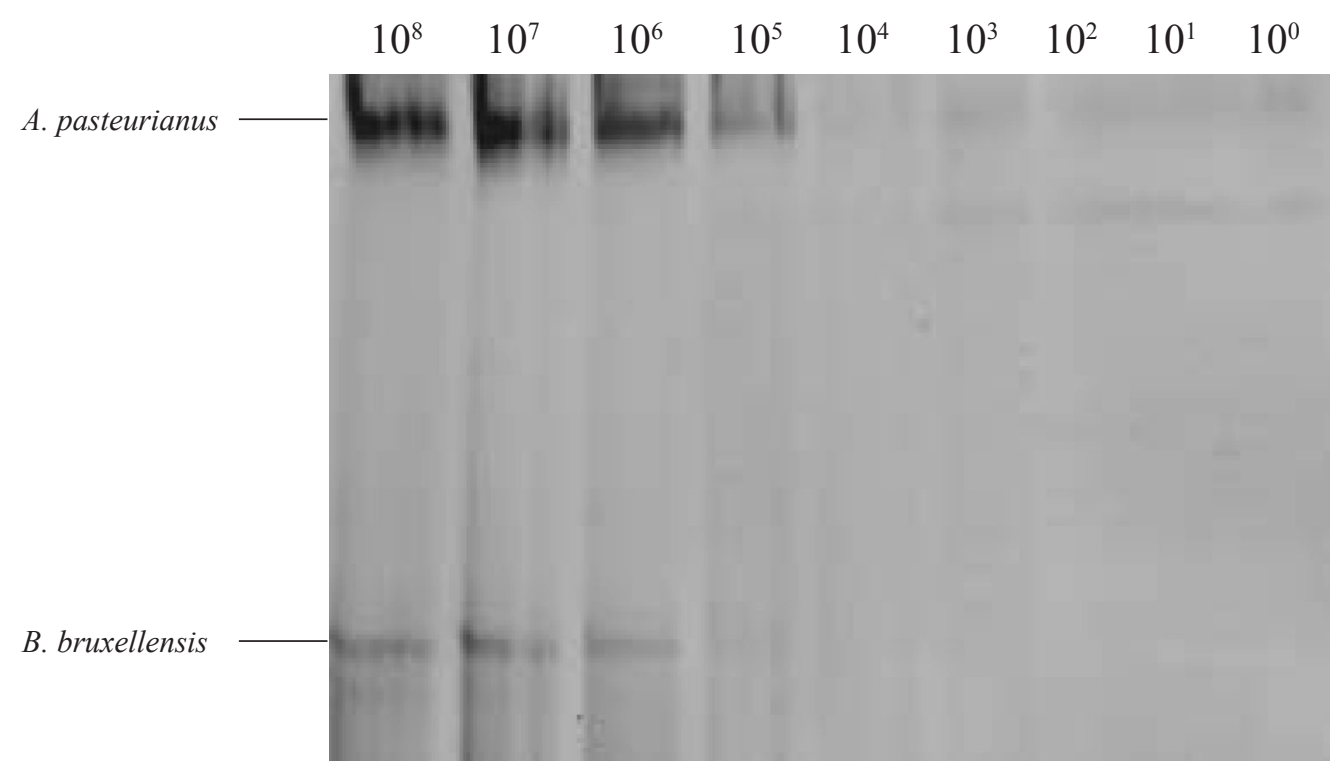

FIGURE 2

DGGE analysis of the different concentrations of A. pasteurianus and B. bruxellensis $\left(10^{8}\right.$ to $\left.10^{\circ} \mathrm{cfu} / \mathrm{mL}\right)$ inoculated into sterile white wine as a mixture and amplified with the primers HDA1 ${ }^{\mathrm{GC}}$ and HDA2. 


\section{TABLE 4}

PCR and DGGE detection limits for the inoculation of sterile saline solution and sterile white wine with mixed populations $\left(10^{8} \mathrm{cfu} / \mathrm{mL}\right.$ of each strain).

\begin{tabular}{|c|c|c|c|c|c|c|c|c|c|c|}
\hline \multirow{2}{*}{ Microbe } & \multirow{2}{*}{ Medium } & \multirow{2}{*}{ Primers } & \multicolumn{4}{|c|}{ PCR detection limit (cfu/mL) } & \multicolumn{4}{|c|}{ DGGE detection limit (cfu/mL) } \\
\hline & & & $1^{\mathrm{a}}$ & $2^{\mathrm{b}}$ & $3^{\mathrm{c}}$ & $4^{\mathrm{d}}$ & 1 & 2 & 3 & 4 \\
\hline \multirow[t]{4}{*}{ A. pasteurianus } & SSS & HDA $1{ }^{\mathrm{GC}} / \mathrm{HDA} 2$ & $10^{1}$ & $10^{1}$ & $\mathrm{NI}^{\mathrm{e}}$ & $10^{1}$ & $10^{3}$ & $10^{1}$ & $\mathrm{NI}$ & $10^{1}$ \\
\hline & & $\mathrm{WBAC} 11^{\mathrm{GC}} / \mathrm{WBAC} 2$ & $10^{1}$ & $10^{1}$ & $\mathrm{NI}$ & $10^{1}$ & $10^{1}$ & $10^{5}$ & NI & $10^{1}$ \\
\hline & White wine & $\mathrm{HDA} 1{ }^{\mathrm{GC}} / \mathrm{HDA} 2$ & $10^{1}$ & $10^{1}$ & NI & $10^{1}$ & $10^{1}$ & $10^{5}$ & NI & $10^{7}$ \\
\hline & & $\mathrm{WBAC} 1^{\mathrm{GC}} / \mathrm{WBAC} 2$ & $10^{1}$ & $10^{1}$ & NI & $10^{1}$ & $10^{1}$ & $10^{5}$ & NI & $10^{2}$ \\
\hline \multirow[t]{4}{*}{ L. plantarum } & SSS & $\mathrm{HDA} 1^{\mathrm{GC}} / \mathrm{HDA} 2^{\prime}$ & $10^{1}$ & NI & $10^{1}$ & $10^{1}$ & $10^{3}$ & NI & $10^{1}$ & $10^{1}$ \\
\hline & & $\mathrm{WBAC} 1^{\mathrm{GC}} / \mathrm{WBAC} 2$ & $10^{1}$ & NI & $10^{1}$ & $10^{1}$ & $10^{1}$ & NI & $10^{4}$ & $10^{1}$ \\
\hline & White wine & $\mathrm{HDA}^{\mathrm{GC}} / \mathrm{HDA} 2$ & $10^{1}$ & NI & $10^{1}$ & $10^{1}$ & $10^{4}$ & $\mathrm{NI}$ & $10^{1}$ & $10^{1}$ \\
\hline & & $\mathrm{WBAC} 1^{\mathrm{GC}} / \mathrm{WBAC} 2$ & $10^{1}$ & NI & $10^{1}$ & $10^{1}$ & $10^{1}$ & NI & $10^{5}$ & $10^{2}$ \\
\hline \multirow[t]{2}{*}{ B. bruxellensis } & SSS & $\mathrm{HDA}^{\mathrm{GC}} / \mathrm{HDA} 2$ & NI & $10^{1}$ & $10^{1}$ & $10^{1}$ & NI & $10^{1}$ & $10^{1}$ & $10^{1}$ \\
\hline & White wine & $\mathrm{HDA} 1{ }^{\mathrm{GC}} / \mathrm{HDA} 2$ & NI & $10^{1}$ & $10^{1}$ & $10^{1}$ & NI & $10^{6}$ & $10^{1}$ & $10^{1}$ \\
\hline
\end{tabular}

${ }^{\mathrm{a}} 1=$ combination of $A$. pasteurianus and $L b$. plantarum.

${ }^{\mathrm{b}} 2=$ combination of $A$. pasteurianus and B. bruxellensis.

'3 = combination of Lb. plantarum and B. bruxellensis.

$\mathrm{d} 4=$ combination of $A$. pasteurianus, $L$. plantarum and $B$. bruxellensis.

${ }^{\mathrm{e}} \mathrm{NI}=$ not inoculated.

primers could not amplify the yeast DNA from B. bruxellensis. When compared to the PCR detection limits of the single reference microbial strains, it was observed that the same PCR detection limit was determined using the universal primers (HDA1 $\left.{ }^{\mathrm{GC}}-\mathrm{HDA} 2\right)$, but that a higher detection limit of $10^{3} \mathrm{cfu} / \mathrm{mL}$ was observed for B. bruxellensis inoculated into white wine when amplified with the HDA1 ${ }^{\mathrm{GC}}-\mathrm{HDA} 2$ primers.

The PCR amplicons were successfully resolved on a DGGE gel and a DGGE detection limit of $10^{1} \mathrm{cfu} / \mathrm{mL}$ was determined for $A$. pasteurianus and B. bruxellensis when inoculated into SSS and when amplified with the universal primers. When amplified with the WBAC1 ${ }^{\mathrm{GC}}-\mathrm{WBAC} 2$ primers, a DGGE detection limit of $10^{5} \mathrm{cfu} / \mathrm{mL}$ was obtained for $A$. pasteurianus (Table 4). When the inoculation was done in white wine, DGGE detection limits of $10^{5}$ $\mathrm{cfu} / \mathrm{mL}$ and $10^{6} \mathrm{cfu} / \mathrm{mL}$ was determined for A. pasteurianus and B. bruxellensis respectively, using HDA $1^{\mathrm{GC}}-\mathrm{HDA} 2$ (Table 4, Fig. 2). A DGGE detection limit of $10^{5} \mathrm{cfu} / \mathrm{mL}$ was also observed for A. pasteurianus in white wine when amplified with the bacteriaspecific primers (Table 4).

The two primer pairs had a similar sensitivity for the amplification of this wine bacterium (A. pasteurianus) when simultaneously inoculated with a wine yeast. When compared to the results obtained from the inoculation of the single microbial reference strains (Table 3), it was observed that lower detection limits were obtained for the inoculation of the single microbial strains than when inoculated as part of a mixed microbial population. When inoculated as a mixture at a concentration of $10^{8} \mathrm{cfu} / \mathrm{mL}$, B. bruxellensis and A. pasteurianus had lower DGGE detection limits, of $10^{1} \mathrm{cfu} / \mathrm{mL}$, than when either of these two strains was inoculated as a single strain in SSS $\left(10^{2} \mathrm{cfu} / \mathrm{mL}\right.$ and $10^{4} \mathrm{cfu} / \mathrm{mL}$ for A. pasteurianus and B. bruxellensis respectively). The reason for these findings is uncertain, and no similar studies on these microbes have been reported in the literature. Therefore, further research is needed to explain why a lower detection limit was observed for these microbial species in a mixed population than as single microbial strains.

\section{Lactobacillus plantarum and Brettanomyces bruxellensis}

When L. plantarum and B. bruxellensis were inoculated into SSS and white wine and amplified with the HDA $1{ }^{\mathrm{GC}}-\mathrm{HDA} 2$ primers, as well as WBAC1 ${ }^{\mathrm{GC}}-\mathrm{WBAC} 2, \mathrm{PCR}$ detection limits of $10^{1} \mathrm{cfu} /$ $\mathrm{mL}$ were determined for both the wine bacterium and the yeast (Table 4). When L. plantarum and B. bruxellensis were inoculated into SSS and amplified with HDA $1^{\mathrm{GC}}-\mathrm{HDA} 2$, a DGGE detection limit of $10^{1} \mathrm{cfu} / \mathrm{mL}$ was determined for both these microbes. When amplified with the WBAC1 ${ }^{\mathrm{GC}}-\mathrm{WBAC} 2$ primers a higher DGGE detection limit, of $10^{4} \mathrm{cfu} / \mathrm{mL}$, was determined for $L$. plantarum when compared to amplification with the universal primer pair (Table 4). When L. plantarum and B. bruxellensis were inoculated into white wine, a DGGE detection limit of $10^{1} \mathrm{cfu} / \mathrm{mL}$ was determined for both the microbial species. PCR amplicons that were amplified with the $\mathrm{WBAC} 1^{\mathrm{GC}}-\mathrm{WBAC} 2$ primers were resolved with DGGE analysis and gave a detection limit of $10^{5}$ $\mathrm{cfu} / \mathrm{mL}$ for L. plantarum.

When compared to the results obtained for the inoculation of the single microbial strains (Table 3), it was observed that higher DGGE detection limits, of $10^{4} \mathrm{cfu} / \mathrm{mL}$ and $10^{3} \mathrm{cfu} / \mathrm{mL}$, were obtained for $B$. bruxellensis inoculated as a single microbial strain and when amplified with HDA $1{ }^{\mathrm{GC}}-\mathrm{HDA} 2$ in SSS and white wine respectively. Regarding the DGGE detection limits, it was also observed that the $\mathrm{WBAC} 1^{\mathrm{GC}}-\mathrm{WBAC} 2$ primer pair was more sensitive when L. plantarum was inoculated as a single strain 
than when inoculated with $B$. bruxellensis. The results with the HDA $1^{\mathrm{GC}}-\mathrm{HDA} 2$ primer pair compared well when $L$. plantarum was inoculated as a single strain and when it was inoculated as part of a mixed population. A DGGE detection limit of $10^{1} \mathrm{cfu} /$ $\mathrm{mL}$ was obtained for $L$. plantarum when inoculated as a single microbial strain and as part of a mixed microbial population, and DGGE detection limits of $10^{1} \mathrm{cfu} / \mathrm{mL}$ and $10^{2} \mathrm{cfu} / \mathrm{mL}$ were determined when inoculated as a single microbial strain and as part of a mixed population respectively.

\section{Acetobacter pasteurianus, Lactobacillus plantarum and Bretta- nomyces bruxellensis}

The PCR and DGGE detection limits determined for the inoculation of the mixed population of $A$. pasteurianus, L. plantarum and $B$. bruxellensis into SSS and white wine are given in Table 4 . The PCR detection limit for all three of the microbes was determined as $10^{1} \mathrm{cfu} / \mathrm{mL}$ when inoculated into SSS and white wine and when amplified with both the HDA $1^{\mathrm{GC}}-\mathrm{HDA} 2$ and $\mathrm{WBAC} 1^{\mathrm{GC}}$ WBAC2 primer pairs. Since the bacteria-specific primer pair WBAC1 ${ }^{\mathrm{GC}}-\mathrm{WBAC} 2$ is not specific for the amplification of yeast species, it was not expected that this primer pair would amplify $B$. bruxellensis, and thus there is no detection limit for $B$. bruxellensis when amplified with WBAC1 ${ }^{\mathrm{GC}}-\mathrm{WBAC} 2$.

The DGGE detection limits for the reference microbes inoculated into SSS as part of a mixed population were determined at $10^{1}$ $\mathrm{cfu} / \mathrm{mL}$ when amplified with both primer pairs (Table 4). When inoculated into white wine and amplified with the HDA $1{ }^{\mathrm{GC}}-\mathrm{HDA} 2$ primers, a DGGE detection limit of $10^{1} \mathrm{cfu} / \mathrm{mL}$ was determined for L. plantarum and B. bruxellensis, while a DGGE detection limit of $10^{7} \mathrm{cfu} / \mathrm{mL}$ was determined for $A$. pasteurianus. When the two bacterial species and the yeast species were inoculated into white wine and amplified with the $\mathrm{WBAC} 1{ }^{\mathrm{GC}}-\mathrm{WBAC} 2$ primers, a DGGE detection limit of $10^{2} \mathrm{cfu} / \mathrm{mL}$ was determined for both the bacterial species. The results indicate that the $\mathrm{WBAC}^{\mathrm{GC}}-\mathrm{WBAC} 2$ primer pair was more sensitive and specific in the amplification of the wine bacteria than the HDA $1{ }^{\mathrm{GC}}-\mathrm{HDA} 2$ primers, and that it could detect lower concentrations of the bacterial species.

When compared to the inoculation of single microbial strains in SSS and white wine (Table 3), it was observed that the DGGE detection limits were lower, at $10^{1} \mathrm{cfu} / \mathrm{mL}$ for the three microbial species, than when inoculated as single strains in SSS. It was also observed that the DGGE detection limits were lower for the reference microbial strains when inoculated as part of a mixed population into white wine, with the exception of $A$. pasteurianus, which had a DGGE detection limit of $10^{7} \mathrm{cfu} / \mathrm{mL}$ when inoculated in white wine as a single microbial strain.

\section{CONCLUSIONS}

The results obtained in this study indicate that PCR-DGGE analysis can successfully be used for the detection of the potential wine spoilage microbes $P$. pentosaceus, L. plantarum, A. pasteurianus and $B$. bruxellensis, both as single microbes and as part of mixed populations inoculated into SSS and white wine. However, it is extremely important to optimise the PCR and DGGE conditions that will be used in the assay. PCR and DGGE conditions were successfully optimised for $P$. pentosaceus, L. plantarum, A. pasteurianus and $B$. bruxellensis with a universal, a bacteriaspecific and a yeast-specific primer pair. These optimised DGGE profiles can be used presumptively to identify microbial species present in wine samples by constructing a reference ladder. It was found that the yeast-specific primer pair could not amplify low concentrations of microbial cells.

\section{LITERATURE CITED}

Andorrà, I., Landi, S., Mas, A., Guillamón, J.M. \& Esteve-Zarzoso, B., 2008. Effect of oenological practices on microbial populations using culture-independent techniques. Food Microbiol. 25, 849-856.

Cocolin, L., Bisson, L.F. \& Mills, D.A., 2000. Direct profiling of the yeast dynamics in wine fermentations. FEMS Microbiol. Lett. 189, 81-87.

Di Maro, E., Ercolini, D. \& Coppola, S., 2007. Yeast dynamics during spontaneous wine fermentation of the Catalanesca grape. Int. J. Food Microbiol. 117, 201-210.

Ercolini, D., 2004. PCR-DGGE fingerprinting: novel strategies for detection of microbes in food. J. Microbiol. Meth. 56, 297-314.

Fleet, G.H., 1993. The microorganisms of winemaking - isolation, enumeration and identification. In: Fleet, G.H. (ed). Wine microbiology \& biotechnology. Taylor \& Francis, New York. pp. $1-26$.

Giraffa, G. \& Neviani, E., 2001. DNA-based, culture-independent strategies for evaluating microbial communities in food-associated ecosystems. Int. J. Food Microbiol. 67, 19-34.

Hernán-Gómez, G., Espinosa, J.C. \& Ubeda, J.F., 2000. Characterization of wine yeasts by temperature gradient gel electrophoresis (TGGE). FEMS Microbiol. Lett. 193, 45-50.

Hugenholtz, P. \& Pace, N.R., 1996. Identifying microbial diversity in the natural environment: a molecular phylogenetic approach. Trends Biotechnol. 14, 90-97.

Kopke, C., Cristovão, A., Prata, A.M., Silva Pereira, C., Figueiredo Marques, J.J. \& San Romão, M.V., 2000. Microbiological control of wine. The application of epifluorescence microscopy method as a rapid technique. Food Microbiol. 17, 257-260.

Lodhi, M.A., Ye, G.N., Weeden, N.F. \& Reisch, B.I., 1994. A simple and efficient method for DNA extraction from grapevine cultivars, Vitis species and Ampelopsis. Plant Mol. Biol. Rep. 12, 6-13.

Lopez, I., Ruiz-Larrea, F., Cocolin, L., Orr, E., Phister, T., Marshall, M., VanderGheynst, J. \& Mills, D.A., 2003. Design and evaluation of PCR primers for analysis of bacterial populations in wine by denaturing gradient gel electrophoresis. Appl. Environ. Microbiol. 69, 6801-6807.

Mills, D.A., Johannsen, E.A. \& Cocolin, L., 2002. Yeast diversity and persistence in Botrytis-affected wine fermentation. Appl. Environ. Microbiol. 68, 4884-4893.

Muyzer, G., 1999. DGGE/TGGE: a method for identifying genes from natural ecosystems. Curr. Opin. Microbiol. 2, 317-322.

O’Donnell, K., 1993. Fusarium and its near relatives. In: Reynolds, D.R. \& Taylor, J.W. (eds). The fungal holomorph: mitotic, meiotic and pleomorphic speciation in fungal systematics. CAB International, Wallingford. pp. $225-233$.

Prakitchaiwattana, C.J., Fleet, G.H. \& Heard, G.M., 2004. Application and evaluation of denaturing gradient gel electrophoresis to analyse the yeast ecology of wine grapes. FEMS Yeast Res. 4, 865-877.

Querol, A. \& Ramón, D., 1996. The application of molecular techniques in wine microbiology. Trends Food Sci. Tech. 7, 73-78.

Rankine, B., 1995. Microbiology and fermentation. In: Making good wine - A manual of winemaking practice for Australia and New Zealand. Pan Macmillan, Sydney. pp. $118-130$

Renouf, V., Strehaiano, P. \& Lonvaud-Funel, A., 2007. Yeast and bacteria analysis of grape, wine and cellar equipments by PCR-DGGE. J. Int. Sci. Vigne Vin 41, 51-61.

Rodrigues, N., Gonçalves, G., Pereira-da-Silva, S., Malfeito-Ferreira, M. \& Loureiro, V., 2001. Development and use of a new medium to detect yeast of the genera Dekkera/Brettanomyces. J. Appl. Microbiol. 90, 588-599.

Stahl, D.A. \& Chapman, W.C., 1994. Application of molecular genetics to the study of microbial communities. NATO ASI Series, G35, 193-206.

The South African Wine Laboratories Association, 2002. Methods of analysis for wine laboratories. South African Society for Enology and Viticulture, South Africa.

Wang, S. \& Levin, R.E., 2006. Rapid quantification of Vibrion vulnificus in clams (Protochaca staminae) using real-time PCR. Food Microbiol. 23, 757-761. 